\title{
EFEKTIVITAS MODEL PEMBELAJARAN KOOPERATIF TIPE TWO STAY TWO STRAY DENGAN PENDEKATAN SAINTIFIK DALAM PEMBELAJARAN MATEMATIKA PADA SISWA SMP NEGERI 2 KOTA SORONG
}

\author{
Nika Fetria Trisnawati \\ Fakultas Keguruan dan Ilmu Pendidikan Universitas Muhammadiyah Sorong \\ Jl. Pendidikan KM. 8 Kota Soorng \\ Email: nfetristrisnawati@gmail.com
}

Diterima: 30 Agustus 2017. Dipublikasikan: 1 Oktober 2017

\begin{abstract}
Abstrak
Penelitian ini merupakan penelitian pre-eksperimental design dengan one-group pretestpostestdesign yang bertujuan untuk mengetahui keefektifan pembelajaran statistika melalui Model Pembelajaran Kooperatif Tipe Two Stay Two Stray (TSTS) dengan Pendekatan Saintifik pada kelas VII F SMP Negeri 2 Kota Sorong. Penelitian ini dilaksanakan pada tanggal 2 Mei sampai dengan 2 Juni 2016 di SMP Negeri 2 Kota Sorong.Populasi penelitian ini adalah siswa kelas VII semester genap tahun pelajaran 2015/2016, yang terdiri dari 10 kelas. Teknik pengambilan sampel adalah cluster random sampling. Data tentang aktivitas siswa diperoleh dengan menggunakan lembar observasi, data tentang respon siswa terhadap pembelajaran doperoleh dengan menggunakan lembar angket, data peningkatan self efficacy siswa diperoleh dengan menggunakan lembar angket dan untuk mengetahui hasil belajar materi statistika digunakan tes hasil belajar. Analisis data yang digunakan adalah analisis deskriptif untuk mendeskripsikan keterlaksanaan pembalajaran, aktivitas siswa, respon siswa, self efficacy siswa serta hasil belajar siswa dan analisis inferensial untuk menguji hipotesis penelitian

Hasil penelitian menunjukkan bahwa: (1) keterlaksanaan pembelajaran menggunakan model pembelajaran kooperatif tipe Two Stay Two Stray dengan Pendekatan Saintifik selama 5 kali pertemuan dalam kategori sangat baik, (2) aktivitas siswa dalam kategori sangat efektif, (3) respon siswa terhadap pembelajaran cenderung positif, (4) self efficacy siswa setelah pembelajaran menunjukkan peningkatan dari sebanyak $94 \%$ siswa pada kategori cenderıng, negatif menjadi 94\% siswa pada kategori cenderung positif, (5) hasil belajar siswa menc i ketuntasan belajar 87,88\%, nilai rata-rata 78,58. Dengan demikian dari hasil penelitian dapat disimpulkan bahwa Model Pembelajaran Koopefatif Tipe Two Stay Two Stray dengan Pendekatan Saintifik dalam Pembelajaran Matematika pada Siswa SMP Negeri 2 Kota Sorong pada materi statistika dapat meningkatkan hasil belajar siswa.
\end{abstract}

\section{PENDAHULUAN \\ Latar Belakang}

Pendidikan merupakan kunci dari keberhasilan suatu bangsa. Dengan kata lain pendidikan merupakan tolak ukur kemajuan suatu bangsa. Pembangunan bangsa Indonesia tidak akan terlepas dari peran dunia pendidikan. Pembelajaran pada setiap satuan pendidikan berlangsung melalui pembelajaran berbagai disiplin ilmu.Matematika merupakan salah satu disiplin ilmu yang konsepnya tersusun secara hierarkis dan saling berkesinambungan, dari materi yang mudah atau sederhana meningkat ke yang sulit atau rumit.

Berdasarkan observasi yang dilakukan terhadap siswa kelas VII F SMP Negeri 2 Sorong, ternyata hasil ulangan semester siswa selama 2 tahun terakhir tercatat sebanyak $60 \%$ siswa tidak tuntas, yaitu tidak memenuhi KKM mata pelajaran matematika (KKM: 70). Banyak hal yang menjadi penyebab rendahnya hasil belajar matematika siswa, diantaranya siswa mengalami kesulitan dalam memahami materi matematika sehingga hasil belajar matematika mereka rendah.Kesulitan yang 
dialami siswa dalam memahami materi matematika disebabkan siswa kurang aktif.Siswa tidak berani untuk menanyakan kesulitannya dalam memahami materi maupun dalam mengerjakan soal yang diberikan guru.Inisiatif siswa kurang, hal tersebut nampak ketika guru memberi kesempatan untuk menyelesaikan soal didepan kelas tidak dimanfaatkan dengan baik oleh siswa.Kemandirian siswa dalam belajar juga relatif rendah.Saat pelajaran dimulai siswa kurang serius dalam mengikuti kegiatan pembelajaran, sehingga konsentrasi dalam mengikuti pelajaran kurang.Siswa kurang bertanggung jawab dalam mengerjakan tugas-tugas belajarnya, kurang percaya diri dan terkesan masih malu-malu untuk bertanya kepada guru.Disiplin dalam belajar juga masih kurang, jika guru memberikan soal tidak segera dikerjakan tetapi siswa justru ramai sendiri dan malas untuk mengerjakannya.

Salah satu cara untuk mengatasi kondisi di atas yaitu dengan mengembangkan model pembelajaran yang berpusat pada siswa (Student- Centered). Salah satu model pembelajaran yang relevan dan sesuai dengan permintaan kurikulum ialah model pembelajaran kooperatif.Salah satu tipe model pembelajaran kooperatif adalah Two Stay Two Stray.Penggunaan model pembelajaran kooperatif tipe TSTS akan mengarahkan siswa untuk aktif, baik dalam berdiskusi, tanya jawab, mencari jawaban, menjelaskan dan juga menyimak materi yang dijelaskan oleh teman.Model pembelajaran Two Stay Two Stray ini memberi kesempatan kepada kelompok untuk mengembangkan hasil informasi dengan kelompok lainnya (Hanafiah, 2010). Selain itu, struktur Two Stay Two Stray ini memberi kesempatan kepada kelompok untuk membagikan hasil kesempatan kepada kelompok lain.

Dengan adanya kurikulum yang baru, guru hendaknya mampu memadukan antara model pembelajaran klasikal dengan pendekatan saintifik, sehingga paradigma lama tersebut sedikit demi sedikit dapat berubah ke arah yang lebih baik.Selain itu, guru hendaknya menguasai beberapa model pembelajaran agar paradigma lama tersebut dapat dirubah, tentunya model pembelajaran yang mendukung dan selaras dengan pendekatan saintifik.

Berdasarkan uraian sebelumnya, maka peneliti melaksanakaneksperimentasi model pembelajaran kooperatif tipe Two Stay Two Stray dengan pendekatan saintifik dalam pembelajaranmatematika pada siswa kelas VII F SMP N 2 Sorong. Penelitian inidibatasi pada materi statistika.

\section{Rumusan Masalah}

Dari latar belakang dan masalah di atas maka dapat dirumuskan permasalahan yaitu Apakah penerapan model pembelajaran kooperatif tipe Two Stay Two Stray dengan pendekatan saintifik efektif dalam pembelajaran matematika pada kelas VII F SMP Negeri 2 Sorong?

\section{Tujuan Penelitian}

Dari rumusan masalah yang telah diuraikan di atas, maka tujuan penelitian ini yaitu Untuk mengetahui Apakah penerapan model pembelajaran kooperatif tipe Two Stay Two Stray dengan pendekatan saintifik efektif dalam pembelajaran matematika pada siswa kelas VII F SMP Negeri 2 Sorong.

\section{Manfaat Penelitian}

\section{Manfaat Teoritis}

Secara teoritis penelitian ini dapat dimanfaatkan sebagai salah satu acuan atau landasan teori dalam memilih dan mengembangkan model pembelajaran dengan memperhatikan self-efficacy yang dimiliki siswa. Dengan mengetahui pengaruh penggunaan model pembelajaran terhadap aktifitas, respons, self-efficacy dan hasil belajar siswa, diharapkan dapat menunjukkan seberapa penting variabel tersebut mempengaruhi prestasi belajar matematika siswa.

\section{Manfaat Praktis}

\section{a. Bagi Siswa}

Melalui penelitian ini diharapkan dapat menarik minat belajar, keberanian, dan konsentrasi siswa terhadap matematika. Selain itu, siswa dapat belajar untuk bekerjasama dalam tim, mengemban tanggung 
jawab, serta berperan aktif dalam pembelajaran matematika.

b. Bagi Guru

1) Memperoleh informasi mengenai pembelajaran menggunakan model Two Stay Two Stray dengan pendekatan saintifik terhadap siswa.

2) Membuka wawasan guru akan keberagaman model pembelajaran yang dapat dipilih dan dimanfaatkan dalam proses pembelajaran.

\section{METODE PENELITIAN \\ Jenis Penelitian}

Penelitian ini dikategorikan sebagai penelitian pre-eksperimental design dengan one-group pretest-postestdesign, yaitu penelitian dengan satu kelas eksperimental.
Sugiyono (2015:110) mengemukakan jenis penelitian ini terdapat pretest sebelum diberi perlakuan, dengan demikian hasil perlakuan dapat diketahui lebih akurat, karena dapat membandingkan dengan keadaan sebelum diberi perlakuan.

\section{Desain Penelitian}

Desain dari penelitian ini adalah preeksperimental yaitu one-group pretestpostest design. Dalam penelitian ini terdapat satu kelas eksperimen. Kelas tersebut diberi pretest, kemudian diberi perlakuan menggunakan model pembelajaran kooperatif tipe Two Stay Two Stray (TSTS) dengan pendekatan saintifik, selanjutnya diberi postest untuk melihat keefektifan perlakuan yang diberikan. Skema desain penelitian disajikan dalam tabel berikut:

Tabel 3.1 Desain Penelitian

\begin{tabular}{ccc}
\hline Pre-Test & Treatment & Post - Test \\
\hline $\mathrm{O}_{1}$ & $\mathrm{~T}$ & $\mathrm{O}_{2}$ \\
\hline
\end{tabular}

Sumber: Sugiyono (2015)

Keterangan:

$\mathrm{T} \quad$ : Perlakuan (treatment) dengan model pembelajaran kooperatif tipe Two Stay Two Stray dengan pendekatan Saintifik

$\mathrm{O}_{1} \quad$ : Skor pre-test

$\mathrm{O}_{2} \quad$ : Skor post-test

\section{Definisi Operasional Variabel}

\section{Variabel Bebas}

Variabel bebas pada penelitian ini adalah Model Pembelajaran Kooperatif Tipe Two Stay Two Stray.

2. Variabel Terikat
a. Aktifitas
b. Respons siswa
c. Self-efficacy siswa.
d. Hasil belajar matematika siswa.

\section{Populasi dan Sampel}

\section{Populasi}

Populasi dalam penelitian ini adalah seluruh siswa kelas VII SMP N 2 Kota Sorong tahun pelajaran 20152016 yang terdiri dari 10 kelas paralel. Kemampuan ke 10 kelas adalah homogen.Kelas VII merupakan kelas yang homogen karena pemilihan pada saat penentuan siswa untuk menempati kelas tidak menurut peringkat dan tidak menurut jenis kelamin.

\section{Sampel}

Teknik pengambilan sampel dalam penelitian ini adalah Cluster Random Sampling. Yaitu memilih satu kelas secara random dari 10 kelas untuk menetapkan kelas sebagai unit eksperimen yang akan diterapkannya model pembelajaran kooperatif tipe Two Stay Two Stray (TSTS) dengan pendekatan saintifik.

\section{Instrumen Penelitian dan Teknik Pengumpulan Data \\ 1. Instrumen Penelitian \\ a. Lembar observasi aktivitas guru Lembar observasi aktivitas guru merupakan instrument yang digunakan}


untuk mengumpulkan data tentang keterlaksanaan pembelajaran yang diisi oleh observer.

b. Lembar observasi aktivitas siswa

Lembar observasi aktivitas siswa digunakan untuk menjaring aktivitas siswa selama pembelajaran matematika.

c. Angket respons siswa

Lembar angket respons siswa digunakan untuk memperoleh informasi dari siswa tentang pelaksanaan pembelajaran matematika dengan menggunakan model TSTS dengan pendekatan saintifik.

d. Tes Self Efficacy

Self-efficacy siswa diperoleh dengan menggunakan metode angket. Angket self efficacy terdiri dari 28 pernyataan dengan 14 pernyataan positif dan 14 pernyataan negatif.

e. Tes hasil belajar

Tes hasil belajar pada penelitian ini dikembangkan dalam bentuk uraian sesuai dengan materi.

\section{Perangkat Pembelajaran}

a. Rencana Pelaksanaan Pembelajaran

Rencana pelaksanaan pembelajaran dibuat berdasarkan sintaks pembelajaran kooperatif tipe TSTS dengan pendekatan saintifik

b. LKS

Lembar kerja siswa yang dibuat dalam penelitian ini sesuai dengan penerapan model TSTS dengan pendekatan saintifik

c. Buku Siswa

Buku siswa adalah buku pegangan siswa yang digunakan dalam pembelajaran kooperatif tipe TSTS dengan pendekatan saintifik pada materi statistika kelas VII.

\section{HASIL DAN PEMBAHASAN \\ Uji Normalitas}

1. Data Hasil Belajar Siswa
Pada pengujian normalitas untuk data postest dan data gain ternormalisasi siswa diperoleh bahwa data uji normalitas hasil belajar siswa diperoleh nilai $p$-value $=$ 0,200 untuk uji normalitas KolmogorovSminov. P-value lebih besar dari $\alpha=0,05$ berarti data hasil belajar berasal dari data berdistribusi normal.

\section{Data Self-Efficacy siswa}

Pada pengujian normalitas untuk data akhir angket self-efficacy siswa dan gain ternormalisasi dari angket self-efficacy siswa diperoleh nilai $p$-value $=0,200$ Untuk uji normalitas Kolmogorov-Sminov. P-value lebih besar dari $\alpha=0,05$ berarti data akhir angket self-efficacy siswa berasal dari data berdistribusi normal.

\section{Uji Hipotesis}

Model kooperatif tipe TSTS dengan pendekatan saintifik efektif untuk diterapkan dalam pembelajaran matematika di kelas VII F SMP N 2 Sorong. Untuk pengujian hipotesis dirumuskan juga $\mathrm{H}_{0}$ dan $\mathrm{H}_{1}$ Sebagai berikut:

$\mathrm{H}_{0}$ : Model kooperatif tipe TSTS dengan pendekatan saintifik tidak efektif untuk diterapkan dalam pembelajaran matematika di kelas VII F SMP N 2 Sorong

$\mathrm{H}_{1}$ : Model kooperatif tipe TSTS dengan pendekatan saintifik efektif untuk diterapkan dalam pembelajaran matematika di kelas VII F SMP N 2 Sorong

Hipotesis mayor dalam penelitian ini akan diuji berdasarkan hasil pengujian hipotesis minor. Hasil pengujian hipotesis minor dalam penelitian ini sebagai berikut:

a. Hipotesis Minor

1) Hasil Pengujian Hipotesis Minor 1

$$
\mu_{1}>69,9
$$$$
\mathrm{H}_{0} \mu_{1} \leq 69,9 \text { Lawan } \mathrm{H}_{1:}
$$

Dimana $: \mu_{1}=$ Parameter

skor rata-rata hasil belajar siswa

Hasil pengujian hipotesis minor 1 dapat dilihat berdasarkan pada tabel 4.19 tentang nilai rata-rata hasil belajar siswa 
Tabel 4.17 hasil Pengujian One-Sample Test Hipotesis Minor 1 One-Sample Test

\begin{tabular}{|c|c|c|c|c|c|c|}
\hline & \multicolumn{6}{|c|}{ Test Value $=69.9$} \\
\hline & \multirow[t]{2}{*}{$\mathrm{t}$} & \multirow[t]{2}{*}{$\mathrm{df}$} & \multirow[t]{2}{*}{$\begin{array}{l}\text { Sig. }(2- \\
\text { tailed) }\end{array}$} & \multirow[t]{2}{*}{$\begin{array}{c}\text { Mean } \\
\text { Difference }\end{array}$} & \multicolumn{2}{|c|}{$\begin{array}{l}95 \% \text { Confidence Interval of the } \\
\text { Difference }\end{array}$} \\
\hline & & & & & Lower & Upper \\
\hline ostest & 5.760 & 32 & .000 & 8.67576 & 5.6075 & 11.7440 \\
\hline
\end{tabular}

Berdasarkan tabel 4.17 terlihat bahwa $p$-value $<0,001<\alpha=0,05$ maka $\mathrm{H}_{0}$ ditolak sehingga $\mathrm{H}_{1}$ diterima untuk hipotesis minor 1 .

\section{2) Hipotesis Minor 2}

Hipotesis minor 2 berhubungan dengan rata-rata gain ternormalisasi siswa yang diajar dengan pembelajaran kooperatif tipe TSTS dengan pendekatan saintifik pada siswa kelas VII F SMP Negeri 2 Kota
Sorong haruslah lebih besar dari 0,29. Untuk keperluan pengujian statistik, maka dirumuskan hipotesis kerja sebagai berikut:

$\mathrm{H}_{0} \mu_{\mathrm{g}} \leq 0,29$ Lawan $\mathrm{H}_{1:} \mu_{\mathrm{g}}>0,29$

Dimana $\mu_{\mathrm{g}}=$ parameter skor ratarata gain ternormalisasi siswa

Hasil pengujian hipotesis minor 2 dapat dilihat berdasarkan pada tabel 4.19 tentang nilai gain ternormalisasi. Pengujian hipotesis menggunakan SPSS 20 dengan menggunakan uji t one-sample test berikut:

Tabel 4.18 hasil Pengujian One-Sample Test Hipotesis minor 2

\begin{tabular}{|c|c|c|c|c|c|c|}
\hline \multicolumn{7}{|c|}{ One-Sample Test } \\
\hline & \multicolumn{6}{|c|}{ Test Value $=0.29$} \\
\hline & $\mathrm{t}$ & $\mathrm{df}$ & $\begin{array}{l}\text { Sig. (2- } \\
\text { tailed) }\end{array}$ & $\begin{array}{c}\text { Mean } \\
\text { Difference }\end{array}$ & $\begin{array}{r}95 \% \text { Confidenc } \\
\text { Diffe }\end{array}$ & $\begin{array}{l}\text { erval of the } \\
\text { e }\end{array}$ \\
\hline & & & & & Lower & Upper \\
\hline n_gain & 48.557 & 32 & .00 & .42667 & .4088 & .4446 \\
\hline
\end{tabular}

Berdasarkan tabel 4.18 terlihat bahwa $p$-value $<0,001<\alpha=0,05$ maka $\mathrm{H}_{0}$ ditolak sehingga $\mathrm{H}_{1}$ diterima untuk hipotesis minor 2 .

3) Hipotesis Minor 3

$$
\text { Untuk menguji hipotesis }
$$

'Ketuntasan Klasikal Siswa Lebih dari 74,9\%', statistik inferensial yang digunakan adalah proportion test.

Hipotesis statistik untuk keperluan uji statistik dirumuskan sebagai berikut:

$\mathrm{H}_{0}: \pi \leq 0,749$ melawan $\mathrm{H}_{1}$ : $\pi>0,749$, dengan:

$\pi$ : parameter ketuntasan belajar secara klasikal.

Statistik $\mathrm{z}$ yang didapat yaitu $\mathrm{z}=$ 1,67 , dengan $z_{\text {tabel }}=(0,5-\alpha)=0,45=1,645$. Terlihat bahwa 1,67 lebih besar dari $\mathrm{z}_{\text {tabel }}=$ 1,645 , sesuai dengan uraian pada BAB III jika $z_{\text {hitung }}>z_{\text {tabel }}$, maka $\mathrm{H}_{0}$ ditolak. Karena $\mathrm{H}_{0}$ ditolak, maka $\mathrm{H}_{1}$ diterima.

\section{4) Hipotesis Minor 4}

Hasil pengujian hipotesis minor 4 , berhubungan dengan rata-rata skor selfefficacy siswa setelah pelaksanaan proses pembelajaran dengan model pembelajaran kooperatif tipe TSTS dengan pendekatan saintifik pada pembelajaran matematika statistik kelas VII F SMP Negeri 2 Kota Sorong mencapai kategori cenderung positif yaitu lebih dari 2,49. Untuk keperluan pengujian secara statistik, maka dirumuskan hipotesis kerja sebagai berikut:

$$
\begin{array}{r}
\mathrm{H}_{0}: \mu_{2} \leq 2,49 \text { Lawan } \mathrm{H}_{1} \\
: \mu_{2}>2,49 \\
\text { Dimana } \mu_{\mathrm{e}}=\text { Parameter } \\
\text { skor rata-rata self-efficacy siswa } \\
\text { Hasil pengujian hipotesis minor } 4 \\
\text { dapat dilihat berdasarkan pada tabel } 4.19 \\
\text { tentang skor self-efficacy siswa. Pengujian } \\
\text { hipotesis menggunakan SPSS 20 dengan } \\
\text { menggunakan uji t } \text { one-sample test berikut: }
\end{array}
$$


Tabel 4.19 hasil Pengujian One-Sample Test Hipotesis Minor 4 One-Sample Test

\begin{tabular}{|c|c|c|c|c|c|c|}
\hline & \multicolumn{6}{|c|}{ Test Value $=2.49$} \\
\hline & & & \multirow[t]{2}{*}{$\begin{array}{l}\text { Sig. }(2- \\
\text { tailed) }\end{array}$} & \multirow[t]{2}{*}{$\begin{array}{c}\text { Mean } \\
\text { Difference }\end{array}$} & \multicolumn{2}{|c|}{$\begin{array}{c}95 \% \text { Confidence Interval of } \\
\text { the Difference }\end{array}$} \\
\hline & & & & & Lower & Upper \\
\hline ostest_efikasi & 12.441 & 32 & .000 & .61758 & .5165 & .718 \\
\hline
\end{tabular}

Berdasarkan tabel 4.19 terlihat bahwa $p$-value $<0,001<\alpha=0,05$ maka $\mathrm{H}_{0}$ ditolak sehingga $\mathrm{H}_{1}$ diterima untuk hipotesis minor 4 .

\section{KESIMPULAN DAN SARAN Kesimpulan}

Berdasarkanbasilpenelitiandanpernba hasanpadaBabIVmakakesimpulan dalarnpenelitianiniadalah model pembelajaran kooperatif tipe Two Stay To Stray (TSTS) dengan pendekatan saintifik efektif diterapkan dalam pembelajaran matematika pada siswa kelas VII SMP Negeri 2 Kota Sorong, sesuai dengan hasil penelitian sebagai berikut:

1. Aktivitas keterlaksanaan proses pembelajaran dengan menggunakan model pembelajaran kooperatif tipe TSTS dengan pendekatan saintifik sangat sesuai dan efektif.

2. Aktivitas siswa dalam pencapaian pembelajaran Statistika melalui model pembelajaran kooperatiftipe TSTS denganpendekatan saintifikpada kelas VII SMPNegeri2 Kota sorongberadadalamkategori sangatefektif.

3. Respon siswa dalam pembelajaran Statistika melalui model pembelajarankooperatiftipe TSTS denganpendekatan saintifikpada kelas VII SMPNegeri2 Kota sorongberadadalamkategoricenderung positif

4. Rata-rata skor angket self-efficacy siswa pada pembelajaran kooperatif TSTS dengan pendekatan saintifik pad siswa kelas VII F SMP Negeri 2 Kota Sorong berada pada kategori cenderung positif.

5. Rata-rataskor hasil belajar matematika siswa dalam pembelajaran Statistika melalui

model pembelajarankoopcratiftipe

TSTS

denganpendekatan saintifikpada

kelasVII

Kotamencapainilai rata-rata78,58

dengan sekitar $87,88 \%$ siswa memenuhi kriteria ketuntasan

minimal(KKM)sehinnga

pembelajaran

mencapaiketuntasanklasik.

\section{Saran}

Berdasarkan kesirnpulanpenelitian yang telah diuraikan diatas, maka ada beberapasaranyangpenelitisampaikan sebagai berikut:

1. Pembelajaran Statistikamelalui model pembelajarankooperatiftipe TSTS denganpendekatan saintifik perludipertimbangkansebagaisalahsaru alternatif

pembelajarandemimeningkatkanhasilb elajarsiswapadamateristatistika.

2. Bagi yangingin melakukan atau mengernbangkan lebih Ianjut penelitianini,diharapkanmencermati keterbatasanpenelitian inisehinggahasilpenelitian yangdilakukandapatlebihefektif.

3. Penelitiansernacaminiseyognyanyadila kukan juga padapokokbahasan lain.

\section{DAFTAR PUSTAKA}

A.M. Sardiman. 2011. Interaksi dan Motivasi Belajar Mengajar. Jakarta: Rajawali.

AgusSuprijono.2009.CooperativeLearning TeoridanAplikasiPAIKEM.Yogyakart a: Pustaka Pelajar.

Aqib, Zainal. 2014. Model-Model, Media, dan Strategi Pembelajaran Kontekstual (Inovatif). Bandung: Yrama Widya.

Ardin.2012. Efektifitas Pembelajaran Matematika RealistikSetting 
Kooperatif tipe NHT dapat Menjadi Solusi $d$ ari Pemecahan Masalah dalam Pembelajaran Matematika di $\begin{array}{lllll}\text { kelas } & X & \text { SMA Negeri } 1\end{array}$ Kulisusu.Tesis.Tidak diterbitkan.Makassar :PPs UNM

Arikunto, Suharsimi. 2013. Dasar-dasar Evaluasi Pendidikan Cet.2. Jakarta: Bumi Aksara

Aziz Wellang,2015. Keefektivan Pembelajaran Sistem Persamaan Linear Dua Variabel Melalui Model Pembelajaran Kooperatif Tipe Numbered Head Together dengan Pendekatan Realistik pada Kelas VIII SMP Negeri 2 Pengsid Kabupaten Sidenreng Rappang.Tesis.Tidak diterbitkan. Makassar: PPs UNM

Cecep Sumarna. 2004. Filsafat Ilmu. Dari hakikat menuju nilai.Bandung : Pustaka Bani Quraisy

Dahar, Ratna Wilis. 2011. Teori-Teori Belajar dan Pembelajaran. Bandung: Erlangga

Hamalik, Oemar. 2005. Proses Belajar Mengajar. Jakarta: Bumi Aksara. Oemar. 2012. Kurikulum dan Pembelajaran. Jakarta: PT. Bumi Aksara

Hamdani. 2010. Strategi Belajar Mengajar. Bandung : Pustakan Setia Bandung.

Hamzah, Ali. 2014. Evaluasi Pembelajaran Matematika Cet.2. Jakarta: Kharisma Putra Utama Offset

Hanafiah, Nanang \& Cucu Suhana. 2010. Konsep Strategi Pembelajaran. Bandung: Refika Aditama.

Huda, Miftahul. 2011. Cooperatif Learning. Metode, Teknik, Struktur dan Model Penerapan. Yogyakarta: Pustaka Pelajar.

Ilyas, B \& Tiro, M. A. 2007.Statistika Terapan untuk Ilmu Ekonomi dan Ilmu Sosial Edisi Kedua. Makassar: Andira Publiser

Johnson, Elaine. B. 2009. CTL (Contextual Teaching \& Learning). Bandung: Kaifa

Kamus Besar Bahasa Indonesia (KBBI) versi digital, 2010, http://ebsoft.web.id

Kemendikbud.2013. Permendikbud No.65 tentang Standar Proses Pendidikan
Dasar dan Menengah. Jakarta:

Kementerian Pendidikan dan

Kebudayaan

$\begin{array}{lcc}2013 . & \text { Permendikbud } \\ \text { No.81A } & \begin{array}{c}2013 \text { tentang } \\ \text { Implementasi }\end{array}\end{array}$

Kurikulum. Jakarta: Kementerian

Pendidikan dan Kebudayaan

2013. Pelatihan

Pendampingan Kurikulum 2013

Pendekatan Saintifik. Jakarta: Pusat Pengembangan Tenaga Kependidikan.

Kismawati, 2015.Pengembangan Perangkat Penilaian Autentik dalam Pembelajaran Statistika pada Siswa Kelas X SMA.Tesis.Tidak diterbitkan. Makassar: PPs UNM.

Lalita, Tania Vidyadwisi, Agustus 2014, "Hubungan antara Self Efficacydengan Kecemasan pada Remaja yang Putus Sekolah" Jurnal Psikologi Klinis dan Kesehatan Mental.Vol. 03 No. 2, Agustus 2014, http://journal.unair.ac.id

Lie, Anita. 2008. Cooperative Learning Cet.6. Jakarta: PT. Grasindo.

Moh.Uzer Usman.2006. Menjadi Guru Profesional. Bandung: Remaja Rosdakarya.

Mukhid, Abd. 2009. "Self-Efficacy (PerspektifTeoriKognitifSosialdanIm plikasinya terhadap pendidikan)". Tadrîs. Volume

4.Nomor1.2009.http://download.port algaruda.org/article.php.

Nurdin Hasnawati. Desember 2012."Penerapan Metode Tutor Sebaya pada Mata Pelajaran Kimia untuk Meningkatkan Self- Efficacy Siswa Kelas XII Pertanian SMKN 1 Watang Pulu Sidrap". Jurnal Chemica Vo/. 13 Nomor 2 Desember 20 12,17-25.

http://download.portalgaruda.org/article.ph $\mathrm{p}$ ? article $=98662 \& \mathrm{val}=4338$.

Riduwan dan Sunarto. 2007. Pengantar Statistika. Bandung : Alvabeta

Rusman, 2014.Model-Model Pembelajaran Mengembangkan Profesionalisme Guru. Jakarta: Rajawali Pers.

Sagala, Syaiful, 2006."Konsep dan makna pembelajaran".Bandung, Alfabeta, 
Sanjaya, Wina. 2009. Penelitian Tindakan Kelas. Jakarta : Kencana.

Sardiman. 2011. Interaksi dan Motivasi Belajar Mengajar. rev.ed. Jakarta: Raja Grafindo Persada.

Slameto. 2010. Belajar dan Faktor-Faktor yang Mempengaruhinya. Jakarta: Rineka Cipta..

Suarni, Waode. 2012. "Memprediksi Prestasi Akademik Mahasiswa Berdasarkan Efikasi Diri Dan Stres Akademik". Gema edisi juli 2012.https://gemapendidikanfkipuho. files.wordpress.com/2014/01/3gema-edisi-juli-2012.pdf

Sudjana, Nana, Ahmad Rivai. 2007. Teknologi Pengajaran. Bandung: Sinar Baru Algesindo

Sudjana, Nana. 2005. Dasar-Dasar ProsesBelajar Mengajar. Bandung: Sinar BaruAlgensindo Offset. .2005. Penilaian Hasil Proses Belajar Mengajar. Bandung: Remaja Rosdakarya

Sugiyono. 2015. Metode Penelitian Pengembangan. Bandung: Alfabeta.

Sujarweni, V. Wiratna. 2014. Metodologi Penelitian. Yogyakarta: Pustaka Baru Press

Syah, Muhibbin. 2008. Psikologi Pendidikan dengan Pendekatan Baru. Bandung: Remaja Rosdakarya.

Trianto. 2007. Model Pembelajaran Terpadudalam Teori dan Praktek. Jakarta: Prestasi Pustaka.

2009. Mendesain Model Pembelajaran Inovatif - Progresif. Jakarta: Kencana Prenada Media Group.

Uno, B. Hamzah. 2006. Orientasi Baru dalam Psikologi Pembelajar.Jakarta : PT. Bumi Aksara

Uno, B. Hamzah. 2014. Model Pembelajaran Menciptakan Proses Belajar Mengajar yang Kreatif dan Efektif. Jakarta: PT. Bumi Aksara.

Viqriah, Khafittulloh, dkk. Desember 2015. "EksperimentasiModel Pembelajaran Think-Pair-Share (Tps), Think-TalkWrite (Ttw) DanTwoStay-Stray(Tsts) PadaMateriBangunRuang SisiDatar DitinjauDariSelf-Efficacy". JMEE Volume V Nomor 2, Desember 2015, http://www.jurnal.fkip.uns.ac.id/inde x.php.

Walgito, Bimo. 2003. Psikologi Sosial (Suatu Pengantar).Yogyakarta : Andi Offset.

Warsita, Bambang. 2008. Teknologi Pembelajaran Landasan \& Aplikasinya. Jakarta: Rineka Cipta

Wibawa, Wigih Adi. 2012. "Teori Belajar Konstruktivisme". http/wiare.blogspot.com/html. Diunduh 2 Juni2013.

Woolfolk, A. 2007.Educational psychology $\left(10^{\text {th }} e d\right)$. Boston, MA: Pearson Education.

Zulkosky,K.2009.SelfEfficacy:AConceptAnalysis.Journ al Compilation.44:93-102. 
